\title{
A Circular Economy Approach to Sustain the Souss River, Morocco, Ecosystem Services
}

\author{
Moha Haddouch \\ Regional Department for Agricultural, Circular Economy Project Management Unit, Agadir POB 13/S 84000, Morocco
}

\begin{abstract}
This article discusses the role of the Souss river in disaster risk reduction, climate change adaptation and sustainable development through mainstreaming natural capital into macro-economic policies. The river course, rising from several headstreams in the high Atlas mountain and flowing westward for $180 \mathrm{~km}$ to the atlantic ocean is the beating heart of the Argan biosphere reserve. Its alluvial basin ensures the vital link between biodiversity and the population's utility functions for more than three million inhabitants. It is one of Morocco's most fertile regions where citrus fruits, vegetables, olives are grown beside an argan natural grove, and many of them are for export. Recent growing concern of local authorities tackles natural disasters and subsequent social issues associated to climate change, resource scarcities and flooding damages, especially after the 2014 flood events. This situation paved the way for local NGO incentives to embrace an ecological civilization approach for reconciliation with the Souss river. The local option adopted is to reverse the trend of intensive modern agriculture through a counterbalancing circular economy approach towards an agro-ecological producing pattern in order to sustain the river water balance.
\end{abstract}

Key words: Souss river, ecosystem services, disaster risk reduction, environment engineering.

\section{Introduction}

The Kingdom of Morocco is located in North Africa and has an area of $710,850 \mathrm{~km}^{2}$, bound by the Mediterranean sea to the north, the Atlantic ocean to the west, Algeria to the east and Mauritania to the south. It has a population of around 35 million.

It is one of the North African region's most hazard-prone countries and the economy is frequently affected by dry spells, floods, landslides and invasion by locusts. Parts of the country are also exposed to seismic risk, 12,000 people lost their lives in a massive earthquake in the coastal town of Agadir in 1960. Cities and rural communities also face the danger of sea-level rise and desertification as a result of climate change, according to United Nations Office for Disaster Risk Reduction (UNISDR) [1].

As a result of climate change, the country is particularly vulnerable to flooding and marine flooding, droughts and locust attacks, fires, landslides and

Corresponding author: Moha Haddouch, master, research field: mainstreaming ecosystem services into management policies. mudslides, heat waves and cold spells and sandstorms. In Morocco, the average annual cost of natural disasters would be 5.6 billion Moroccan Dirhams [2].

By far, flooding is the most costly of all hazards in Morocco. Davos global risk forum indicated that flooding causes around $\$ 0.44$ billion in losses each year (Table 1), and UNISDR prevention web estimates that over 23,478 people in the country are exposed to potential flooding and associated losses of life and economic damage. The Table 1 provides the estimated current annual losses after a 20 year period of return by occupancy.

The rains that cause flooding are often of greater intensity and localized, making it difficult to predict and apply appropriate management solutions. The case of the violent storms that hit southern morocco in November 2014 caused widespread flooding, killing 47 people. Thousands of adobe houses were destroyed and more than 100 roads were cut by the flood waters. Souss and Noon watersheds were affected by further flooding in December that left population isolated and inaccessible with a minimum of 3,000 families [3]. 
Table 1 Estimated annual losses of floods at the national level.

\begin{tabular}{lcc}
\hline Occupancy & Average annual loss (USD) & Return period (20 years) \\
\hline Residential & 1,895 & 9,399 \\
Commercial & 434 & 1,965 \\
Industrial & 471 & 2,072 \\
Essential F & 369 & 1,913 \\
Infrastructure & 1,210 & 3,152 \\
All exposures & 4,380 & 18,501 \\
\hline
\end{tabular}

This article will focus on the Souss river and the role it plays in disaster risk reduction, climate change adaptation and sustainable development through mainstreaming natural capital into macro-economic policies.

\subsection{The Souss River Hydraulic System}

The Souss hydraulic unit is situated in sub-saharan Morrocco whose characteristics are extreme aridity in summer, important irregularity of river's regime and great spatio-temporal variability of rains. It covers an area of about $16,156 \mathrm{~km}^{2}$, including $75 \%$ of mountain areas.

Administratively, the Souss area covers the province of Taroudant, the Inezgane Ait Melloul prefecture and a significant part of Agadir Ida Outanane prefecture. According to the 1994 census, the population was 1.54 million people, $53 \%$ in rural areas. Projections indicate that this population would be 2.64 million in 2020 .

Its position near the ocean and the influence of the canarian cold current mitigate this climate and the Anti Atlas mountains barrier helps protect against the southern hot winds. Average rainfall is $280 \mathrm{~mm}$ for the Souss basin.

The Souss watershed is situated between the 30th and the 31 st parallel north, and $9^{\circ}$ west longitude of Greenwich. The term Souss designates a broad area that includes a plain of the same name, the north-western slopes of the Anti-Atlas and south western flanks of the high Atlas. The watershed area forms a sort of triangle open to the ocean, consisting of isolated plain between two recent massive Paleozoic mountains including:

- In north: the western high Atlas chain, a long splitting line between the Souss watershed and the Tensift sub-basins. This Alpine chain rises to 4,167 m in Jbel Toubkal.

- In south: the anticlinal bowing of the western Anti-Atlas culminates at an altitude of $2,531 \mathrm{~m}$. It is made essentially of Cambrian limestone and many Precambrian buttonholes.

- In east, Siroua: a highly faulted connection area covered with Tertiary volcanic flows.

The rugged topography, the varied rocks, the semi-arid climate, the proximity of the desert and strong winds make it an area exposed to erosion and desertification. Demographics and agricultural transformations worsen the situation in dwindling natural resources such as natural vegetation and water [4].

The Souss basin is draining 390 million $\mathrm{m}^{3} /$ year of water through the Issen wadi and the high Souss tributaries [5].

The five large hydraulic structures in the basin (Table 2) made it possible to mobilize an average year nearly 330 million $\mathrm{m}^{3}$ for irrigation of nearly 50,000 ha, accounting for $93 \%$ supply of drinking water of Agadir city and artificial groundwater recharge Souss (nearly 162 million $\mathrm{m}^{3} /$ year).

In addition to large dams, small dams and some hilly lakes are also constructed for irrigation, livestock watering, and flood control purposes.

The Souss renewable groundwater extending on an area of $4,150 \mathrm{~km}^{2}$ is estimated at 200 million $\mathrm{m}^{3}$. Intensive modern agriculture caused a deficit in its replenishment from 100 million $\mathrm{m}^{3} /$ year to 370 million $\mathrm{m}^{3} /$ year with a steady decrease in the piezometric level estimated at $0.5 \mathrm{~m} /$ year to $3 \mathrm{~m} /$ year [5]. 
Table 2 The main hydraulic dams of the Souss river.

\begin{tabular}{llcc}
\hline Dams & Entry into service & Capacity $\left(\mathrm{million} \mathrm{m}^{3}\right)$ & Regulated volume $\left(\mathrm{million}^{3}\right)$ \\
\hline Dkhila & 1986 & 0.7 & - \\
Abdelmoumen & 1981 & 214 & 68.5 \\
Aoulouz & 1991 & 108 & 18 \\
Moukhtar Soussi & 2001 & 50 & 45 \\
Imi El Kheng & 1993 & 11 & 5.5 \\
Total & - & 483.7 & 137 \\
\hline
\end{tabular}

Ninety percent of water is utilized in agriculture, the main economic activity of the Souss with 134,300 ha of irrigated lands of which about $60 \%$ is irrigated modern way dedicated to market gardening $34 \%$, citrus $25 \%$, Cereals $10 \%$ and livestock $28 \%$. The production of citrus and early vegetables contributes over $50 \%$ of the volume of national exports [4].

\subsection{Flood's Genesis and Propagation in the Souss} River

The floods of Oued Souss appear suddenly in the cold season and are commonly brief. Their violence and great speed of spreading are typical of floods in the arid and sub-arid zone.

Data collected from the main hydraulic stations (Aoulouz, Taroudant and Ait Melloul) show that flood pulses occur in November and January.

The watershed upstream area of the Aoulouz dam is the most sensitive to winter and autumn floods: $72 \%$ of floods occur at this period.

The flood propagation speed varies from $5 \mathrm{~km} / \mathrm{h}$ to 8 $\mathrm{km} / \mathrm{h}$ upstream (aoulouz-taroudant) and from $10 \mathrm{~km} / \mathrm{s}$ to $20 \mathrm{~km} / \mathrm{s}$ between Taroudant and Ait Melloul.

During thirty five years (1956-1988), three genetic flood classes were observed, and among the 24 floods of Souss, 7 are flooding from the western Atlas and middle Souss, 2 are floods of the upstream Souss, and
15 are generalized mix floods. The return period of floods with flow $1,500 \mathrm{~m}^{3} / \mathrm{s}$ at Ait Melloul is 5 years.

The floods of Oued Souss appear suddenly in the cold season and are commonly brief. Their violence and great speed of spreading are typical of floods in the arid and sub-arid zone [6].

The erosion risks distribution (Table 3) shows that average potential erosion risk is varying according to terrain, climate and soil properties between 340 $\mathrm{t} / \mathrm{ha} /$ year to $660 \mathrm{t} / \mathrm{ha} /$ year. The Abdelmoumen and Issen basins extending on $50 \%$ of the souss basin recorded the highest values [7].

The aridity and torrential rainfall are the salient aspects of climate in Souss watershed. The combination of these two elements classify soil loss through erosion - a major ecological problems of Souss. $25 \%$ of the watershed area looses more than 50 t/ha/year.

This degradation of the vegetative habitat is largely due to the poor management of forest in the sake of rapid economic benefits regardless of the environment, something that is beginning to be considered.

In sum, soil erosion and the subsequent siltation of the main dams, built during the last 25 years were fostered due to the specific soil physical characteristics, including steep slopes and relatively high rainfall. Most of these dams had already lost 40 percent of their

Table 3 The erosion intensity distribution in the Souss valley.

\begin{tabular}{lrc}
\hline Erosion intensity & Area (ha) & $\%$ \\
\hline Low & 417,908 & 23 \\
Medium & 474,496 & 27 \\
High & 904,580 & 50 \\
Total & $1,796,984$ & 100 \\
\hline
\end{tabular}


reservoir capacity [19]. For these reasons, the Moroccan government has made them a priority watershed requiring immediate action.

\subsection{Souss Flash Floods 2014}

Significant and widespread rainfall lashed the Souss basin from November 27 to 30, 2014 and has caused extensive human and material damages.

During that period, $255 \mathrm{~mm}$ were abated against an average of $19 \mathrm{~mm}$ for the whole month of November and peak floods reached $2,600 \mathrm{~m}^{3} / \mathrm{s}$ at the Taroudant station.

Despite the benefits drawn from these precipitations (dam reservoir replenishment from $61 \%$ to $91 \%$, drinking water security, underground reservoir replenishment, pasture reestablishment), many casualties were reported, including:

- Damage to some parts of the roads;

- Several people drowned;

- Isolation of some communities;

- Several technical facilities damage;

- Damage to drinking water supply systems.

The agency basin flood warning system which consists of 30 warning stations and 9 dams equipped with radios linked to the regional and national headquarters, in addition to 65 people were mobilized to follow this event on the ground.

Sixty field emergency interventions were processed to decode some centers isolated and protect some equipment from flooding. And an emergency investment to build protecting dams and equipments for a total of 240 Millions MAD in the coming 3 years was designed [8].

At the central level, the Moroccan interdepartmental command post which included representatives from the interior, health, infrastructure, transport and environment, as well as representatives of the national electricity and water office was mobilized. Its task is to monitor and assess the situation in the flood-hit regions as well as coordinating joint actions for prevent further risks.
Another emergency program of 245,067 CHF funded by the Disaster Relief Emergency Fund (DREF) was implemented by the International Federation of Red Cross and Red Crescent Societies. It benefitted to 1,100 families who received basic emergency shelter items and appropriate tools for shelter improvement and/or cleaning [3].

It is worth mentioning that important decisions were made by different government departments to tackle this disaster. However, integration among these structures has been a problem.

To harness the power of coordination among government departments and business corporations, an eco-entrepreneurs network was launched in June 2015. Its mission is to re-group all actors and to strengthen their capacities for more solidarity in case of environmental crises [9].

This article aims to facilitate the debate among government agencies and business corporations on catchment management, which is in order to improve the management of flood risk and understand the role of natural capital in the context of adapting to climate change in the Souss valley. It discusses the role of the river Souss in mitigating the risks of the torrential flooding through the integration of natural capital in the macroeconomic policies of the region.

\section{Methodology}

Increased awareness of risks among local stakeholders of the potential impacts with regard to natural disasters and their social impacts, especially after the November 2014 floods, has encouraged local NGOs and businesses to embrace an eco-ecological civilization approach in order to re-conciliate with the river Souss.

This increased awareness should be coupled with completion of the national integrated risk management initiative and its downscaling at the regional level.

The natural capital approach to flood risk management based on a sustainable use and management of ecosystems incorporating disaster risk 
reduction [10] is suggested to ensure an appropriate connection between the national initiative and the regional efforts.

Thus, the methodology basics of this study are built on the following pillars:

- Effective engagement in the positive approach of Sendai framework for risk reduction 2015-2030 catastrophe and ensure the anchoring of the DRC to the intended national determined contribution;

- Adoption of a proactive and integrated approach to climate risk management through advanced regionalization, involving communities, businesses and NGO's, as well as existing statuary frameworks of actions;

- Implementation of appropriate technologies and solutions suited for local conditions, particularly the experience of the WPM project, which had been served as a success story for institutional development, fund leveraging and technical background;

- Sealing partnerships through a negotiated collective agreement specifying roles and responsibilities.

\section{Discussion}

The Souss river, crossing the watershed south of the western high Atlas to $180 \mathrm{~km}$ is the beating heart of the argan forest biosphere reserve. It connects biodiversity of natural environments to socio-economic utility functions of a population of more than two million inhabitants. This is indeed one of the most fertile regions of Morocco where citrus fruits, vegetables, olives are grown next to a natural argan forest whose products are mainly export-oriented.

The regional GDP of the SM region is estimated at 116 billion dirhams ( $12 \%$ of the national GDP), counting for about $33,200 \mathrm{Dh} / \mathrm{cap}$. The region contributes $80 \%$ for the national export of vegetables, and $50 \%$ for citrus. The overall agro-biodiversity and local products generate a turnover of over 3.5 billion dirhams annually [11].
Despite these economic performances sustained by the Souss basin ecosystem services, environmental crises cost the government tremendous resources. Data at the regional level are missing but estimates at the national level points to $2.75 \%-4.65 \%$ of GDP to recover from environmental crises, and the government designates $4.6 \%$ of the finance bill for social care programs $[12,13]$.

For instance, following the Souss basin flooding event in 2014, the public authorities were challenged with delivering a 300 million design handbook action plan in three years, but the expected outputs are far from reaching the ecosystem balance as far a global catchment management approach is not adopted.

These preliminary economic values urge the need to develop a global and integrated strategy where coordination of all sectoral risk policies should focus on prevention and resilience issues first. That strategy should lay, according a basic study conducted by the World Bank on three priorities: price volatility, natural hazards and risks in agriculture [14].

In doing so, every department should proceed with risk assessments at the regional level, then incorporate disaster risk management in its planning process and collaborate to address the Souss river challenges together.

\subsection{The Argan Biosphere Reserve Management Plan}

The argan biosphere reserve underwent an over exploitation of natural resources during the last century. The development model adopted during the 20th century has in effect depreciated, relegated and suffocated the argan ecosystem [15].

Population growth, intensification of modern agriculture and mass tourism resulted in a strong footprint on water resources. Indeed, the amount of water available per capita fell from $3,500 \mathrm{~m}^{3}$ in 1960 to less than $1,000 \mathrm{~m}^{3}$ in 2000 . Forecasts indicate that the amount of available water per capita will decline to $490 \mathrm{~m}^{3}$ in 2020 , which is below the $500 \mathrm{~m}^{3}$ threshold set by the United Nations. 
In addition, over exploitation of forest resources and range lands has induced a strong imprint on the natural vegetation. This resulted in a $50 \%$ loss of argan tree cover during the last century. This degradation is continuing at a rate of 600 hectares a year.

Moreover, women who play a crucial role in the exploitation of the argan tree are suffering from the consequences of the unfair value added distribution along the argan value chain.

The current business model dominated by intensive agriculture, mass tourism and fishing industry should be rethought by integrating a circular economy approach that should lay the foundations for sustainable development. This could be done by introducing innovative market based conservation instruments.

A circular economy is an economy which balances economic development with environmental and resources protection. It puts emphasis on the most efficient use and recycling of resources and environmental protection. A circular economy features low consumption of energy, low emission of pollutants and high efficiency. It involves applying cleaner production in companies, eco-industrial park development and integrated resource-based planning for development in industry, agriculture and urban areas [16].

In the Argan Biosphere Reserve (ABR) context, the management plan should converge towards Inclusive green growth goals, outlining a three-pronged strategy for pursuing a circular economy approach [16].

Eco-conception by thinking in "environmental systems":

- Tailoring regional inclusive green growth strategies to the ABR management plan, with an emphasis on conservation, sustainable development and supporting issues;

- Building resilience through agro-diversity preservation of the two pillar value chains: argan oil and honey provisioning services;
- Eco-branding the ABR products.

Meet up-front capital needs with innovative financing tools:

- Introducing payment for ecosystem services and fair trade systems within the argan and honey value chains;

- Ensuring an equal value distribution by integrating natural capital and relevant taxation reforms into national accounting.

Promoting the social capital stock:

- Structuring the sector and promoting a collective approach of communication;

- Protection and promotion of human rights enhancement, mainly among poor and indigenous people in ecosystem provisioning areas [17].

\subsection{Water Resource Integrated Development Master} Plan for the Souss Basin

Beside securing water delivery and safeguarding water resources, the Water Resource Integrated Development Master Plan for the Souss basin aims to protect the argan ecosystem and boost the up/downstream solidarity [18].

The average water demand in 2030 is estimated at $654 \mathrm{~m}^{3}$ in the souss basin with a $15 \%$ gap, to satisfy this demand an investment plan of approximately 1,273 billion dollars has been designated.

The forefront objective of the plan (Table 4) consists to mobilize the remaining potential in surface water in northern coastal basins and Oued Souss tributaries not yet regularized [18].

To enhance the environmental solutions, the plan should focus on building dams and laminar lacs, gullies control and reforestation, terracing on a priority basis for those areas with high susceptibility to erosion (over $50 \mathrm{t} / \mathrm{ha} /$ year). In fact, much of the eroded materials are deposited in dams and affect their ability to regulate in particular the Aoulouz dam.

A priori, a study on watershed susceptibility to erosion, decreasing of their storing capacity, the life of the dam and the consequent corrective actions is 
Table 4 Integrated development master plan, consistence of hydraulic infrastructure.

\begin{tabular}{lccc}
\hline Investments & Consistence & Cost (million Dh) & $\%$ \\
\hline Large and medium dams & 6 & 2,247 & 17.6 \\
Small dams and hilly lakes & 28 & 892 & 7 \\
Sea water desalinization plant & 1 & 5,651 & 44.4 \\
brackish water demineralization & - & 145 & 1.1 \\
Effluent treatment & - & 92 & 0.7 \\
Conversion to drip irrigation & - & 3,705 & 29.2 \\
Total & - & 12,732 & 100 \\
\hline
\end{tabular}

crucial to the effectiveness of corrective measures of the management plan.

Finally, water regulation application texts should be released so as to allow water companies to invest in upstream water management. This is more for water quality measures, but could also help the flooding agenda.

\subsection{The Watershed Protection Management Project $(W P M)$}

The Watershed Protection Management (WPM) project [19], conducted from October 2001 to September 2004, aims at reducing soil erosion, improving water quality, reducing pollution and improving watershed management.

The project's activities included planting trees, stabilizing ravines and completing a variety of direct and indirect actions designed to raise the income of the farmers in the watershed. In addition, the project helped create village committees and a woman's cooperative and provided training to farmers on improved agro-forestry and soil conservation techniques.

The impact of the project has been tremendous in terms of both the reduction in soil erosion and the improvements in the daily lives of the project beneficiaries. Due to the success of WPM's income-generating activities, there are new opportunities for productive employment, and men who had long ago left the region in search of work are returning to their homes and their families.

Learned lessons show that there is a scale issue in terms of how effective the natural capital approach can be:
- For small flood events at the local level, intervention using natural capital can be very effective;

- For larger flooding events, both in space and scale, there is a definite need for traditional engineering to complement the natural capital approach;

- Environmentally sensitive flood management structure can provide multiple benefits, by-pass flood channels with high biodiversity, flood retention wetlands for recreation and dams with environmental flow releases. These can also provide recreation, tourism and business opportunities.

The WPM project is in fact a success story that must be duplicated in a way which it demonstrates significant results achieved with limited resources using an approach as following:

- Involves beneficiaries from the start;

- Leverages project funds through partnerships;

- Relies on local talent;

- Applies lessons learned and best practices from previous activities.

\subsection{Integrated Forest Management Projects}

The argan forest is exposed to two types of natural hazards: its geographic location at the front zone of the hottest desert in the globe, and the impacts of climate change on the region (an increase in temperature of $0.6{ }^{\circ} \mathrm{C}$ to $1.1{ }^{\circ} \mathrm{C}$, and a precipitation decrease of $10 \%$ to $15 \%$ by 2020 are expected). Under these new conditions, the supply potential of products and other ecosystem services from argan forest are decreasing drastically. 
Recently, pilot projects were implemented to reverse this trend through natural resources conservation, product enhancement and capacity building. Special support has been given to the development of argan women's cooperatives in the area of the Biosphere Reserve (BR).

The Tamri forest is considered to be a hotspot of biodiversity in the Arganeraie BR. It harbours the second most important nesting area of the bald ibis - one of the most endangered species in the area.

The GTZ, in partnership with the Water and Forest Administration and the "projet arganier" (implemented by social development agency and funded partly by European union) is supporting a women's cooperative in the rural community of Tamri for the sustainable use and conservation of the argan forest. The project aims at involving women in the conservation of natural resources and the value enhancement of argan-related products.

In addition, measures were taken to ensure product diversification and participation in exhibitions and fairs. In 2006, the argan oil was the first Moroccan product registered as Protected Geographical Indication (PGI) in the EU system in line with the Trademark Protection Law Proposals.

The implementation of this project showed that responsibility for land management and use is a sensitive issue, involving property rights. The planting of forest trees remains a controversial issue within the community and requires delicate negotiations, which is notably when it comes to the management of collective land [20].

\subsection{Agriculture Green Morocco Plan}

The new agricultural strategy, Green Morocco Plan, established by the Ministry of Agriculture and Fishing, aims to consolidate the successes achieved and meet new challenges facing Morocco's competitiveness, opening of markets and mitigating climate change impacts [21].

At the Souss Massa Draa region, argan and honey value chains are placed at the forefront priorities of this plan as they are considered to be the main pillars for agro-biodiversity conservation. Therefore, their development is facing the global challenge that needs to be tackled by taking into account the roles of the ecosystem services as they are drawn in the Argan Biosphere Reserve Management Plan [22].

Additionally, the policy implication from a recent study [23] is that attention should be given to water saving technologies in the Souss Massa region, in order to reduce pressures of water as a limiting resource for expanding production of irrigated crops. This action may entail decreasing water assignments in the less competitive crops, such as cereals and pulses, and increasing assignment in the more competitive crops such as fodder, fruits and vegetables.

The development of ecological intensification practices by utilizing and enhancing the contribution of ecosystem services on farmland seems to be another appropriate solution. It will increase productivity per unit area, utilize inputs more efficiently, develop resilience against climatic variability, and minimize impacts on environment. Then, ensure food security, alleviate social burden and ensure long-term sustainability of agriculture.

The concept of ecosystem services includes all benefits derived by human beings from ecosystems as defined and elaborated in the United Nations' Millennium Ecosystem Assessment [24]. In agriculture, there are intermediate and final services. Intermediate services are supporting services such as the biological control of pests, whereas, final services are agricultural products like grains, meat and milk. The market value of food generally reflects the cost of factors of production (land, labor, fuel, cost of fertilizers or seed), but fails to capture the total value of intermediate ecosystem services. Moreover, these ecosystem services are not traded in markets. Therefore, they have a value but no price [25].

Another similar study conducted in New Zealand 
on ecosystem services benefits proved that nitrogen mineralization and biological control of pests benefits could exceed in value the input costs of pesticides and fertilizers on the global scale, even if adopted on only 10 percent of globally utilized arable land.

In a relevant study approaching the contrast between "modernism" and "tradition" in the souss basin, it has also been shown that traditional irrigated agriculture includes numerous positive elements, whereas, modern irrigated agriculture has resulted in several negative aspects [26].

Introducing the circular economy approach through Payment for Ecosystem Services (PES) - a market based instrument, in order to conserve agro-biodiversity and promote local products in the Souss-Massa Drâa region which is a new paradigm aiming to connect ecosystem services users to nature [27].

3.6 Integrated and Comprehensive Risk Management Approach to Cope with the Sendai Framework for Risk Reduction

Morocco is taking steps to join 78 other nations whose governments have created National Platforms for Disaster Risk Reduction to support policies for building resilience to disasters.

With over a third of both its population and GDP at high risk, Morocco ranks 58 among the 85 most vulnerable countries. The increasing rate of urbanization and influence of climate-change related meteorological events (rising average temperature, heat waves, increased intensity and frequency of floods) are only adding to the country's vulnerability.

In response, the Ministry of General Affairs and Governance, in close collaboration with the Ministry of Finance and the Ministry of Interior, is implementing a risk management approach to develop an integrated and comprehensive National Risk Management Strategy and a Risk Management Action Plan. This national probabilistic risk assessment based model will lay the foundation for the integration of disaster risk management into national planning. Ministry of the Interior is also designing community-level resilience plans based on field surveys of perceptions of community risk. The information from the assessment and surveys will be integrated into the country's community development plans. Finally, the Ministry of Agriculture and Marine Fisheries is assessing risks and vulnerabilities in the agriculture sector, some of which are linked to the insurance sector.

Based on these cooperative and multi-sectoral approaches, Morocco's National Strategy for Disaster Risk Management-a step toward the implementation of the Sendai Framework for Risk Reduction is emerging. To identify gaps and unmet needs, the approach includes:

- A review of the existing legislative and institutional frameworks;

- The implementation of the national probabilistic hazard risk assessment to identify risks and define the appropriate next steps;

- The community risk perception survey, while focusing on the most vulnerable communities will lead to the community-based disaster risk management pilot which will provide recommendations for the government's community development plans, thereby, leading to a sustainable approach;

- Finally, the assessment exercise of an insurance mechanism.

\subsection{Institutional Framework and Capacity Development}

Since 1970, Morocco established an emergency preparedness (ORSEC) plan (a generic emergency plan in case of disaster) at the territorial level in order to coordinate disaster risk management efforts.

Today, the responsibility for leading on disaster risk reduction lies within the Department of Environment at the Ministry of Energy, Water, Mines and Environment. But for resilience-building to be 
effective, there must be strong collaboration and coordination across many ministries.

To realize a "whole-of-society" approach to managing the risk of disaster according to the Hyogo Framework for Action 2005-2015, a road map for creating Morocco's National Platform for Disaster Risk Reduction was developed by 40 participants from nine ministries. They are energy, water, mines and environment; general affairs and governance; the interior; health; agriculture; education; finance; tourism and transport. Other experts in urban development, meteorology, engineering, reinsurance and other fields, along with representatives of the Moroccan Red Crescent National Society, UN Children's Fund (UNICEF), UN Development Programme (UNDP) and UN's disaster risk reduction office in the Arab States (UNISDR) as main facilitator joined this platform.

The Department of Environment and the UNISDR initiative to establish a national disaster loss database. Once finalized, it would assess the costs borne by Moroccan households of disasters both large and small, which will help to set a robust system for managing disaster risk and help the country encourage more investment in disaster risk reduction.

In addition, the World Bank is undertaking a probabilistic risk assessment using GIS software elaborated recently within the process of settling a new approach to tackle natural hazards risk management [14].

Under an existing plan to prevent flood risk, Morocco has already developed a forecasting and flood warning system according to the 2011 National Hyogo Framework Progress Report for Disaster Risk Reduction. Morocco intends to develop a geographic information system containing data on natural and technological hazards across the country, which called "GIS-Risk".

However, at the regional level, efforts to downscale these initiatives are still needed. The risk management analysis shows many deficiencies as it is post crisis oriented, expost financing, and lacks coordination among sectoral. Moreover, strategies and most program are overlapping. Many actors are involved but at different speed, and the law text need to be updated.

\subsection{Enhancing Cooperation in Flood Management}

The Natural Capital approach is not any more a compromise, it can bring social and economic advantages, enterprise, social opportunities, health and benefits.

This approach is about integrating the natural capital issues with other measures by identifying economic incentives leading to bad practices and counterproductive measures among projects.

There are politically driven interventions and functionally driven interventions. These do not necessarily need to conflict, although they often do [10].

In fact, floods cause extensive human and material damage, so they are amongst the greatest natural risks for the ABR. There were more than 32 large floods during the last couple of decades and many municipalities have suffered from the devastating effects of floods [8].

To provide authorities with criteria and alternatives for action will minimize human and material losses caused by floods in the basin. The initiative, proposed as an independent project for cooperation, aims to create an appropriate framework for transmitting among different authorities - a methodology which should improve quality of life for their inhabitants after adaptation and testing in this pilot area for each partner.

The expected results are improved professional qualifications and the use of reliable anti-flooding tools based on the dissemination of achieved products (methodology, regulation program of actions and good practices, specific maps, public seminar). In these, an expected reduction of $30 \%-40 \%$ is possible in the human and material damage caused by flooding. The 
cost benefit in the Souss river case has not been calculated but results from benchmark investigations indicate 1:52 ratio (protected areas provide to the Mexican economy the equivalent of at least 52 dollars for each dollar invested from the federal budget ) [28].

The multiple benefits and arguments of the natural approach would enhance this partnership system but it should be linked back to multiple sources of funding, and co-ordination of the funding available for flood risk management is needed.

Payment for Ecosystem Services is one way of funding the provision of services that have multiple outputs, but this needs more scrutiny.

\subsection{Communication for Flood Control}

Reconnect with nature as human species is a must for human survival, but this is not a simple task as memories for flood events are short. A communication strategy should be prepared on the basis of the following guidelines:

- Interconnected flood forums with other national regions can provide a new community base for communication and vision;

- Ecosystem services valuation and data base constitution: there is a role to educate politicians and decision makers and evaluate the benefits of a multiple partner approach. In fact, political will and cultural change are needed to facilitate a practical paradigm shift;

- Communications among sectors are reported to be efficient rather than "silo-thinking" among sectors;

- Public awareness is case of inevitable flooding.

\section{Conclusions}

This paper presented evidence for an ecosystem approach to disaster risk management with regard to flooding, and introduced the technical and institutional aspects at the Souss river catchment scale.

The production and consumption model adopted since early colonial period was based on abundant natural resources and a linear pattern of extraction, production, consumption and disposal. This business model has certainly accelerated economic progress of the Souss region but that was at the expense of natural capital while aggravating social disparities.

In fact, the landscape of the Souss valley has changed, so that its natural capital has been degraded as a result. Fifty percent of argan forests have been removed, $50 \%$ of underground water stock has been depleted and the Souss river has been modified. Methods to help restore this natural capital will impact positively on future catchment management.

Urbanization has also induced intensive human consumption patterns beyond the ability of the argan ecosystem to regenerate its resources. Hence, the challenge is to replace this linear model with a circular economy model.

In order to apply the circular economy principles to the Argan Biosphere Reserve Management Plan, tree major solutions should be undertaken:

- Mainstreaming natural capital into development policies;

- Rehabilitating the argan ecosystems;

- Adopting a good governance that shall protect and promote human rights up/downstream the river course.

More specifically, a study on watershed susceptibility to erosion, decreasing of their storing capacity, the life of the dams and the consequent corrective actions are crucial to the effectiveness of corrective measures of the watershed management plan.

Replication of projects based on sustainable natural resources management and agricultural practices will strengthen the protection of the area's natural resources through reduction of soil loss and protection of natural resources, and will also provide sustainable income to the local population.

Responsibility for land management and use is a sensitive issue, involving property rights, and the planting of forest trees remains a controversial issue within the community and the government which 
requires delicate negotiations.

Switching towards ecological intensification practices in agriculture by utilizing and enhancing the contribution of ecosystem services on farmland coupled with water saving technologies seems to be an appropriate solution for a responsible investment in this vital sector.

Based on these cooperative and multi-sectoral approaches, Morocco's National Strategy for Disaster Risk Management - a step toward the implementation of the Sendai Framework for Risk Reduction is emerging.

Even though, at the regional level, efforts to downscale these initiatives are still needed. The Risk management analysis shows many deficiencies as it is post crisis oriented, expost financing and lacks coordination. Moreover, strategies and most programs are overlapping. Many actors are involved at different speed and the law text needs to be updated.

The Natural Capital approach is not any more a compromise, it can bring multiple benefits and incur arguments to enhance partnership system, but it should be linked back to multiple sources of funding and co-ordination of the funding available for flood risk management.

The concept of natural capital works at the policy level, in infrastructure planning, flood risk management as well as environmental rehabilitation, hence:

- There is a need for more integrated and sustainable infrastructure solutions;

- The current approach to flood risk management in the Souss basin needs to be adapted in order to include the social and natural benefits;

- Effective long term flood management solutions can only be found by fully understanding and valuing social and natural impacts and benefits.

\section{References}

[1] MEM. 2013. The Implementation of the Hyogo Framework for Action. National Progress report.

[2] Messouli Mohamed. 2015. Analysis and Mapping of
Vulnerability to Extreme Weather Events and Estimating Their Impact Costs in Safi-Marrakech \& Souss Massa Regions. Agadir: Regional Observatory for Environment and Sustainable Development.

[3] IFRC. 2015. Emergency Plan of Action Operation Update. Morocco: International Red Cross and Red Crescent.

[4] MAMVA. 1997. "Description and Evolution of the Argan Tree Areas." In the Argan Biosphere Reserve Master Plan Study, 40.

[5] ABH. 2011. "The Souss Massa Hydraulic Plan." Souss Massa Draa Hydraulic Basin Agency. Accessed December 15, 2015. http://www.water.gov.ma/userfiles/file/18_Souss-massa-d $\% \mathrm{C} 3 \%$ A9f.pdf.

[6] Saidi Mohamed Elmehdi. 1994. "Flood's Genesis and Spread in Sub-arid Environment as Exemplified by Oued Souss (Morocco)." Bulletin of the Association of French Geographers 1 (January): 94-111.

[7] Chkirid, M. 1972. Erosion Surveying and Soil Loss Estimation in Souss Watershed-Morocco. Rabat: REF.SO/GTZ-PCDA.

[8] ABH. 2014. The 2014 Floods in the Region of Souss Massa Draa. SMD Hydraulic Basin Agency report.

[9] Jamali, M. 2015. "The Eco-responsible Entrepreneurs in Maroc." In 1st Newsletter, 4208.

[10] NCI. 2014. Exploring the Role of Natural Capital in Flood Risk Management. Summary report.

[11] CRSMD. 2010. Souss Massa Regional Economic and Social Strategy. Souss Massa: Conseil Régional SM Regional Council.

[12] FAO. 2003. Environment Degradation Cost. Rabat: FAO.

[13] PLF. 2015. Draft Finance Bill. Morocco: Ministry of Economy and Finance.

[14] World Bank. 2015. "Protecting Morocco through Integrated and Comprehensive Risk Management." Presented at Project High Lights, Global Facility for Risk Reduction and Recovery.

[15] UNESCO. 2008. Decennal Review of the Argan Biosphere Reserve (1998-2008).” Accessed December 10, 2015.

http://reliefweb.int/sites/reliefweb.int/files/resources/MD RMA006du1.pdf.

[16] World Bank. 2012. Inclusive Green Growth: The Pathway to Sustainable Development. New York: World Bank.

[17] Haddouch, M. 2015. "A Circular Economy Approach to Agro-biodiversity Conservation in the Souss Massa Region of Morocco: Project Case-Study.” Presented at Responsible Natural Resource Economics in Africa Conference (RNEA) 2015.

[18] PDAIR. 2011. Plan Revision Study Director of Water Resources Integrated Development Plan Study Review. 
Agadir: Hydraulic Basin Agency.

[19] USAID. 2005. Morocco Watershed Protection and Management Project. Morocco WPM Final report.

[20] Boussaid, M. 2011. "Arganeraie Biosphere Reserve, Morocco, and the Role of Women's Cooperatives." Presented at First International Symposium on Argan ANDZOA, 2011.

[21] MAPM. 2010. Integrating Climate Change into Morocco Green Plan-“PICCPMV Project". Rabat: Agency for Agricultural Development.

[22] DREFSO. 1999. Argan Biosphere Reserve Management Plan (RBA). Rabat: REF.SO/GTZ-PCDA.

[23] Terry Roe, L., and Rodney Smith, B. W. 2015. The Conjunctive Use of Irrigation Water Over Ime in Morocco. Morocco: UNEP Project.

[24] Millennium Ecosystem Assessment. 2005. Ecosystems and Human Wellbeing: Synthesis. Washington DC: Island Press.

[25] Sandhu Harpinder, Steve Wratten, Robert Costanza, Jules Pretty, John Porter, R., and John Reganold. 2015. "Significance and Value of Non-traded Ecosystem Services on Farmland." Peer J. 3: e762.

[26] Herbert Popp. 1986. "Agriculture under Irrigation in the Souss Valley." In Méditerranée Third Series, 33-47.

[27] UNDP-Morocco. 2013. A Circular Economy Approach to Agro-Biodiversity Conservation in the Souss-Massa Draa Region of Morocco. Rabat: Project Document.

[28] Nature Conservancy. 2009. "Valuing Nature: Protected Areas Provide to the Mexican Economy the Equivalent of at Least 52 Dollars for Each Dollar Invested from the Federal Budget." In the Nature Conservancy Review, 1. 